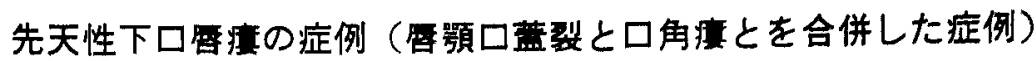

\author{
松 III偣・野忚出践
}

\section{A case of congenital lower lip fistula with lip and palate}

\author{
Noboru Matsuda - Tadayoshi Nonaka
}

はじめに

先天性下日唇瘦は1845年フランス人 Demarquary"に より初めて記截された比校的珍しい奇形で，我国に和い ては曾原》が報告して以来，約30症例に達している。 の奇形と唇顎口蓋裂之の合併正例の報告 ${ }^{3-12)}$ は多いが, さらに口唇の奇形の1つである口角瘦を件発した記述は 極めて少ない

最近，私どる21歳の精神溥弱の男性に見られた，先 天性下口唇瘦と両側性唇顎口蓋裂和よび先天性口角瘦を 合併した1例を維験し，できうる限り家族歴の調查を行 ったので追加報告し，参考に供したい.

$$
\text { 症例 }
$$

\section{患 者 : 21歳 男性 \\ 初診：昭和48年11月日日 \\ 主 訴：口蓋裂による発音障害}

家族歴 3 代にわたって調べたのであるが，表 1に示 すよ5に，祖父母はいとこ同士の結婚であり，本症例を 含めて口長口蓋裂を生じた症例は 5 例，その他の奇形と して鎖肛，精薄に合指症を合併した症例が各 1 例ずつ認 められた。

既往歴：生 後 21 日 目に口唇裂の形成手術を受けてい る、4 月頃より右手に扣るらゃを持たせると落すよら になり，某医で小睍麻瘏によるためと診断された，知能 の発育は遅く，小学校 2 年まではなんとか行動をとるに することはできたが，2年の後期より“てんかん”様の 発作を起こし，当大学精神科を受診し“てんかん”之診 断された．現在まで“抗てんかん剂”の服用を続けてい、 る。現在施設に入園しており，口蓋裂の手術を希望して 当科を受診した。

群馬大学医学部菌科口腔外科（主任：松田登教授） Clinical of Dental and Oral Surgery, School of Medicine, Gunma University (Chief: Prof. Noboru Matsuda)

受付日：昭和51年11月 4 日

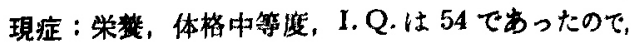

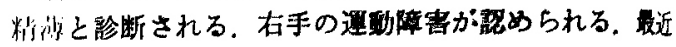
は“てんかん”の発作は起こさないといら。

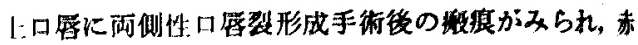

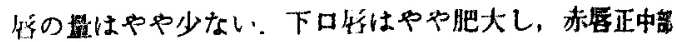
の两側で䄪 $8 \mathrm{~mm}$ の距部をへだて，左右対称に半月犾の

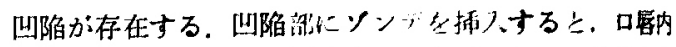

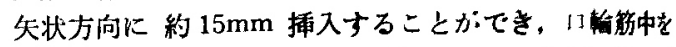
通過して盲端は口唇粘膜下で終っている（写直 1). 周 部る王迫すると，無色透明な粘栍性の液体が流出する。 自覚症状はなく，私どすが指摘するまで本人，家族住下 口唇の症状を特別気にかけていなかった，血液，属など

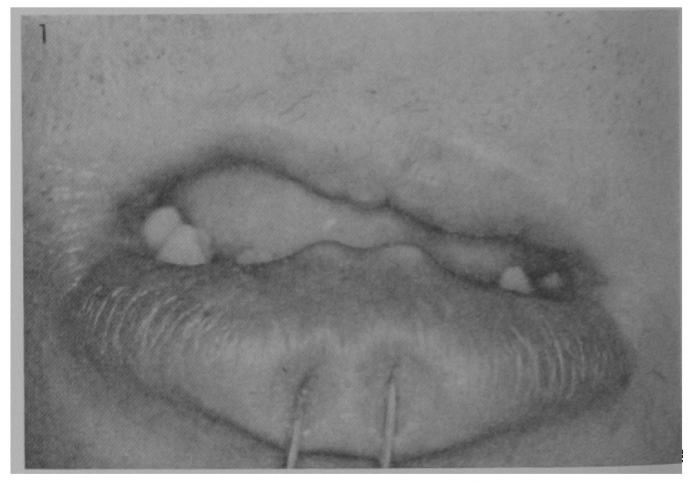

写真 1 下ロ唇膺内ヘソンンデを掅入したところ

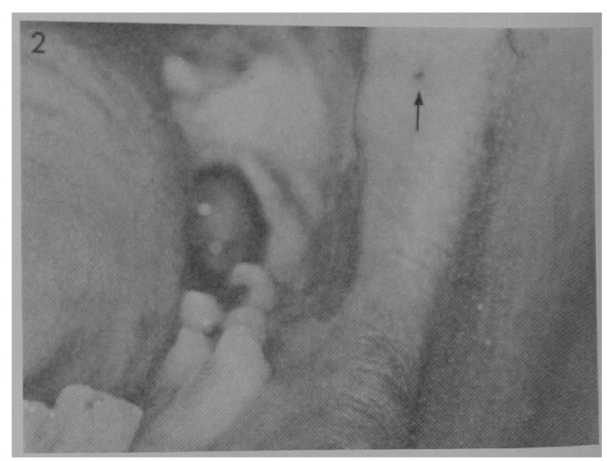

写真 2 矢印は先天性口角灌の部位を示す 


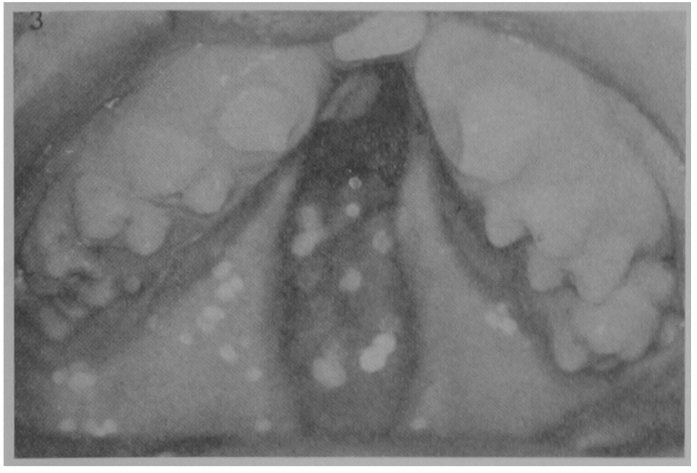

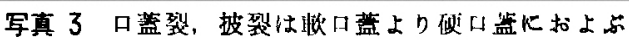

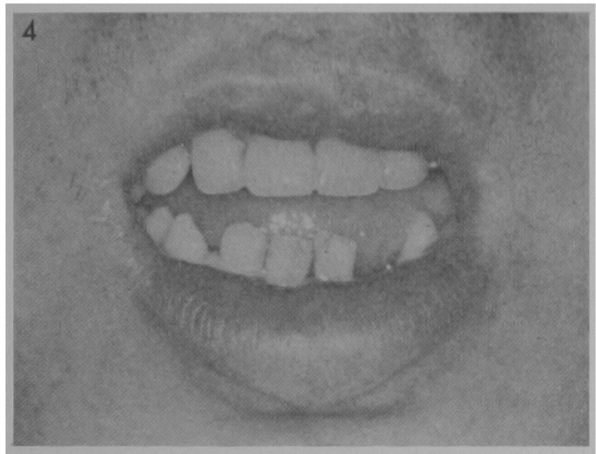

写真 4 得後 2 年半の所見

に異常所見はなく，四肢を始め他の部位に奇形を認めな W.

両側口角部の頓粘膜から外皮覻に移行する部分で， $2 \mathrm{~mm}$ ほど頓粘膜によったところに，帽針頭大の凹陥が 認められ，その中心部は椋孔となりテンデを挿入すると $3 \sim 4 \mathrm{~mm}$ 入る. 口角周辺の煩部老強く王迫しても，分 泌物はしみ出ない（写真 2).

上顎の発育は不良でV字型齿弓を示し, 硬口蓋より軟 口蓋にわたる完全裂があった（写真 3）、Wardill 氏法 口蓋升後方移動術による形成処膡を行った。

処置および経過：口蓋裂の形成手術後, 本人扣よび家 族の希望があったので，瘦孔にゾンデを㨀入して瘦の位 置を確かめながら下口唇瘦周囲に紡錘形の切開を加え， 周囲組織を含めて瘦孔を全摘出するとともに，多少肥大 していた下ロ唇の縮小を計った。手術後約 2 年半を経た 現在でも異常を認めない（写真 4).

口角瘦は審美的見地から，本人の希望かなかったの で、そのままにした。

病理組織所見：瘦孔内壁は重層扁平上皮によって被わ れて扣り，開口部の重層上皮は釗脚が不規則にのびてい る、その表面には軽い角化があるが，異型的なところは ない，瘦孔深部の上皮下に硳液腺が存在し，瘦管に向か って開ロしているものもある（写真 $5 \mathbf{A} ， \mathbf{B}$ ）。

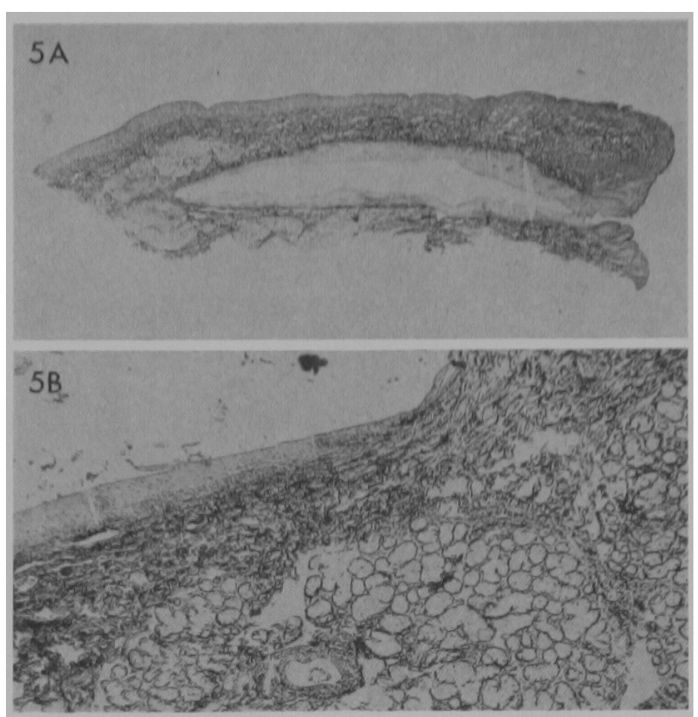

写真 5 病理組織所見. H.E. 染色 Aは瘦管の柸断面 B は瘦管下部の粘液腺

考

按

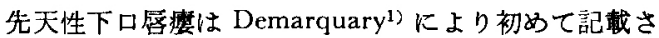
れて以来，数多くの追加報告がなされ，我国においては 菅原 ${ }^{2)}$ ，佐藤 ${ }^{5)}$ ，渡辺 ${ }^{6,11)}$ ，山田 ${ }^{7)}$, 永井 ${ }^{8)}$, 河合 ${ }^{9)}$, 高

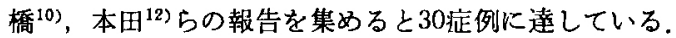
そして，原因，発生頻度，合件奇形，遗伝関係の面から 詳細な検討がなされている。

この奇形は，口蓋裂や口唇裂などの腔領域に起こる 奇形に比べると，わずかに頻度は少ない，唇筫口葐裂の ように審美的，機能的障害が目立たず，下口唇痱たけ単 独に発症したり，窝が小さく分泌物のない軽症の場合 や，また審美的要求の比較的少ない男性ではそのまま放 置されている症例があると思われる，実際の症例数は若 干上まわるはずである。

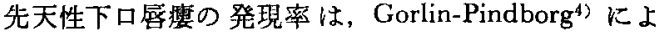
れば，1：200,000人であるとい5が，我国の易合には明 らかではない，本症例のよらに口唇裂口蓋裂と合併して

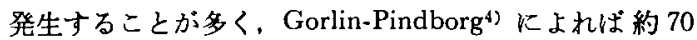
$\%$ ，渡辺 ${ }^{11)}$ の調査による我国の報告例では84\%にも達し ていた

本症例が 合併していた口角瘦は Goldflam ${ }^{13)}$ の記载

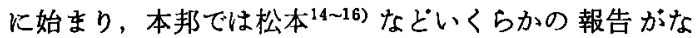

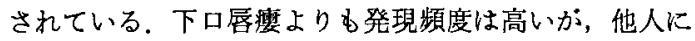
気付かれない位置に生ずること，臨床症状を伴わないな どの理由で，あまり注目をひいていない，角癗に関す る耳鼻科領域の奇形合併症例は，下口唇瘦にくらへて低 
表 1 作将侧家

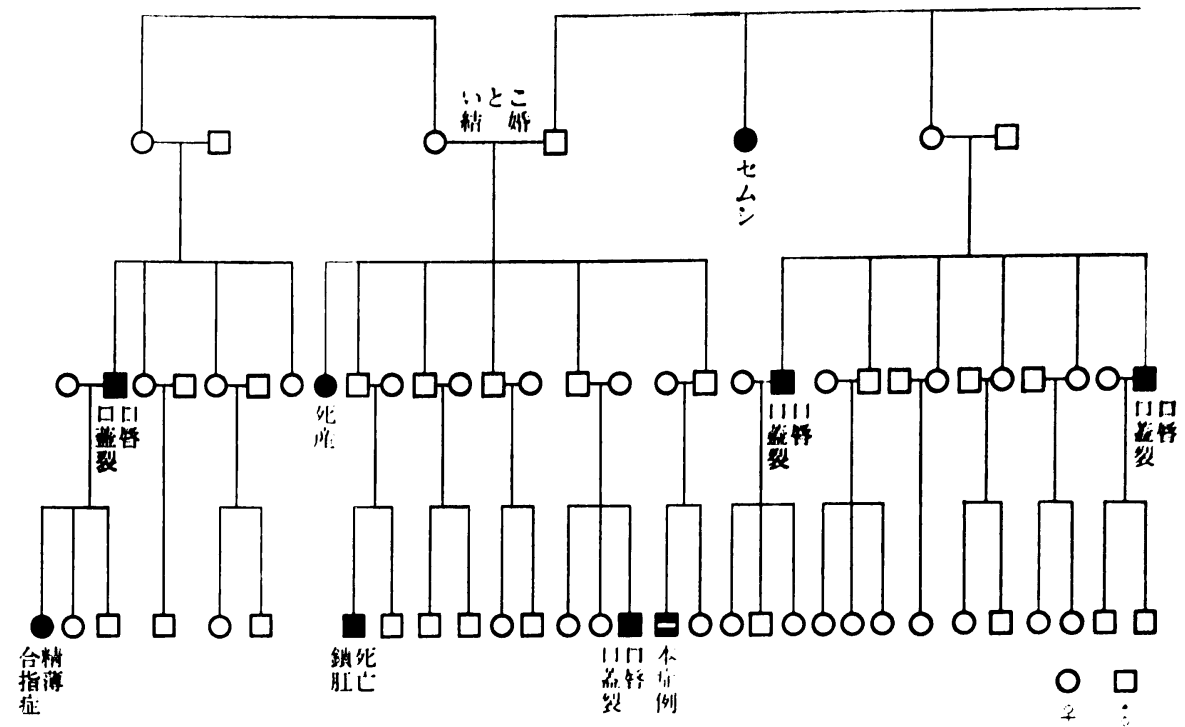

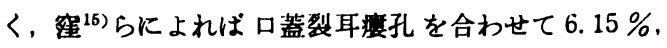
Baker ${ }^{17)}$ は $22.8 \%$ に 2 裂口蓋垂を 合併していたと述へ ている.これらの報告は何れも口唇口蓋裂と合併する可 能性を肯定しており，注目に值する記述と考えられる。

下口唇舾の発生機転については，下居の横清の上皮の 增生沈下説 ${ }^{11)}$ ，鬼居に対し裂を補らために下唇が異常に 発育したといら説 ${ }^{18)}$, 横清の過発育の場合に㾦管に転化 するといら考光，などがなされている。

一方, 口角瘦の成り立ちは下口唇接と巽なり，胎生期 の上類突起と下額突起の蒿合過程がいろいろの原因で妨 げられた場合に生ずるといら説 ${ }^{20)} か ゙$ 有力である。これに 対して, Goldflam ${ }^{13)}$ は下口唇瘦の 発生に関する Stied の説（横溝の過発育のある場合に㾦管に転化するといら 考え）を口角瘦発生に取り上げ，また Lemke 21 ) は口角 瘄が下口唇㾦と発生機序を同一にする可能性を述べてい る.

以上，過去の報告例ならびに発生機転について私たち の症例を検討すると，下口唇瘖と唇䫚口蓋裂とが密接な 関係にあることは納得できるのであるか，口角瘦との合 併については不明な点が多く, 少なくとも我国の文献の 上から見当らないようである。その理由を下口唇㿆と 口角瘦との発生機転の違いに求めれば，本症例は偶然に 両者が併発したといらことになるが，上述のよらに両者 は発生機序を同一にする可能性があるので, 同一発生機 序による本症の発生を全く否定するこ、とはできない，本 症例における口角瘦の存在は，私どもの観察が不十分で あったため再度来院時に確かめられたのである.このよ らなことす起こるので，口角瘦の有無について注意を促 すとともに，今後，本症例と同じないし類似の症例が報
告されることと思われる。

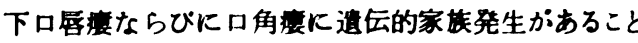
は，かなりの報告例によって証扰つけられている. 本邦

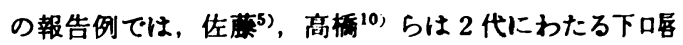

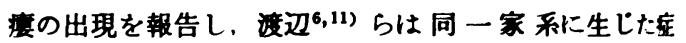

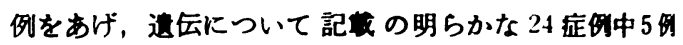
に造伝的関倸が認められたと逨べている．欧米では， Neuman-Schulman ${ }^{22)}$, Soricelli23 らの家系が知られて いる. さらに Gorlin-Pindborg4) は不完全表現事をるつ

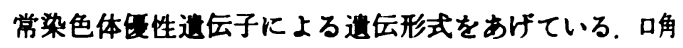

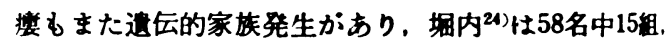
Eissen ${ }^{13)}$ は父子にみられた症例を啹告し，遭云的因子 が口角度の発生に役割を演じていることを示す資料とな っている.

本症例の遗伝的関係については，問診や直接訪問の手 段により，祖父母の代までさかのぼってできるたけ語へ た. 田告のことゆえ調㚗に対して必ずしる協力的ではな かったか，表1に示すよ5に，祖父母は近親結婚であ り，本症例を含めて口居口蓋裂 5 例，鎖肛 1 例，精薄と 合指应の 合 併症 例 1 例，せむし（原因不明）1例を㒛 め, 遗伝的家系であることが碓かめられた. 下口唇零， 口角度については，自覚他覚症状が少ないことによるる のと思われるが不明であった。

本家系では，再度述べることではあるが，疾患ならび に寒美的関心の少ない家族㻴境にあるので，他の口唇・ 口蓋裂症例に口角度を併発している可能性はあると考え られる. 


\section{むす び}

21藏の男性で，両側性唇裂，口蓄裂，両側性先天性口 角瘦を伴った先天性下口唇瘦の症例を述べた，本症例の よらに口角瘦を合侀した症例は非常に少ない，家族歷に

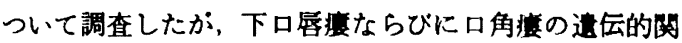
係は口唇・口蓋裂にくらべ明らかではなかった。

本論文の要旨は，昭和50年 9 月第20回日本口弪外 科学会総会で発表した。

\section{文献}

1) Demarquary, T. N.: Quilques considerations sur le bec de-liévre, Gaz Méd, Paris, 13: $52,1848$.

2）菅原 洋：束唇兼先天性下居接の 1 例，日整会 誌, 9: 27, 1933.

3) Gorlin R. J., Goldman, H. M.: Thoma's Oral Pathology. ed 6, Mosby Co, St Louis, 1970, p 918.

4) Gorlin, R. J., Pindborg, J. J.: Syndromes of the head and neck, McGraw-Hill Co, New York, 1964, p 117.

5）佐藤孝三：先天性下口居淮の 3 例，日整会誌， 13: $581,1938$.

6) Watanabe, Y. et al.: Congenital fistulas of the lower lip, OS OM OP, 21: 511, 1966.

7）山田長敬，他：両㑡性唇䫑裂と同時に現われた 下辰瘦の 1 例，九州齿会誌，11：342，1959.

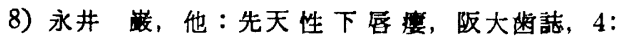
$121,1959$.

9) 河合 幹, 他: 先天性下唇摸を有する 1 例, 愛

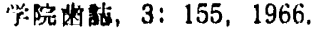

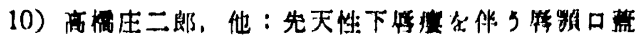

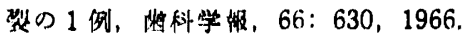

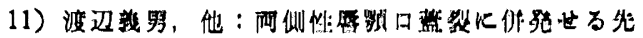
天性下在の1例，口外睆，15：199，1969。

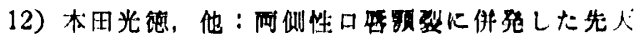
性下口盾の1例，日口外誌，18：124，1972.

13) 出村光一, 他: Mundwinkel fisteln の 1 例, 皮 科の路佅，3:204，1960.

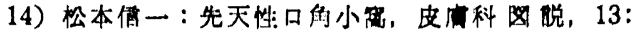
Tab 87, 1930.

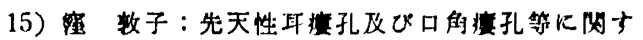
万㽗有，身京女医大誌，23：64，1953.

16）丸山芳郎，他：先灭性口角度孔の研究補邀，臨 床科，14：19，1942.

17) Baker, B. R.: Pit of the lip commissures in Caucasoid males, OS OM OP, 21: 56, 1966.

18) Hilgenreiner, H.: Die angebornen Fisteln lzw schleimhauttaschen der Unterlippe, Dtsch Z. Chir, 188: 273, 1924.

19) Stied A.: Die angebornen Fisteln der Unterlippe und ihre Entstehung, Arch $f$ Klin, Chir, 79: 293, 1906.

20）石川梧朗, 他: 口腔病理学II, 第 3 版, 永米猉 店, 京都, 1975, 558頁。

21) Lemke, G.: U'ber Fisteln der Lippen einschlietzlich der Mundwinkel, Dermat Wschr, 140: 1086, 1959.

22) Neuman, Z., Shulman J.: Congenital sinuses of the lower lip, OS OM OP, 14: 1415, 1961.

23) Soricelli, D. A. et al.: Congenital fistulas of the lower lip, OS OM OP, 21: 511, 1966.

24）堀内純一：先天性口角瘦孔，耳咽喉科臨床， 32: 1039, 1937. 